Çukurova Üniversitesi Mühendislik Fakültesi Dergisi, 36(1), ss. 261-272, Mart 2021

Çukurova University Journal of the Faculty of Engineering, 36(1), pp. 261-272, March 2021

\title{
A Dual-Band Patch Antenna with Improved Gain and Group Delay Characteristics for C-Band and X-Band Applications
}

\author{
Duygu Nazan GENÇOĞLAN ${ }^{1}$, Şule ÇOLAK ${ }^{* 1}$ \\ ${ }^{1}$ Adana Alparslan Türkeş Bilim ve Teknoloji Üniversitesi, Mühendislik Fakültesi, Elektrik- \\ Elektronik Mühendisliği Bölümü, Adana
}

Geliş tarihi: 17.02.2021 Kabul tarihi: 31.03.2021

\begin{abstract}
In this study, a dual-band patch antenna with improved gain and group delay characteristics is proposed for C-band and X-band applications in radar and satellite communications. In the study, conventional square patch antenna is modified by partially removing the ground plane and rounding the patch corners. The radius of the rounded patch corners is determined by parametric study to achieve the best antenna performance. According to this parametric study, the value of the radius is set to $2 \mathrm{~mm}$. Antenna performance is analysed both in frequency and time domains. Return Loss, Voltage Standing Wave Ratio, gain, radiation pattern, and group delay are investigated via CST Microwave Studio program. Experimental study is also performed to verify the simulation results. The results show that the designed antenna with rounded patch corners and partial ground plane has dual band characteristic. The two resonance frequencies are $6.85 \mathrm{GHz}$ and $9.1 \mathrm{GHz}$ in the simulation results, and $6.56 \mathrm{GHz}$ and $9.12 \mathrm{GHz}$ in the measurement results. The antenna has maximum gain of $5.8 \mathrm{~dB}$. Additionally, group delay variation is very small in the related frequency range. Thus, it is verified that, the proposed antenna has enhanced bandwidth, improved gain and more uniform group delay as compared to the conventional square patch antenna. The proposed dual-band antenna is a quite promising structure with its appropriate gain and uniform group delay characteristics for C-band and $\mathrm{X}$-band applications in radar and satellite communications.
\end{abstract}

Keywords: Antenna design, Patch antenna, Gain, Group delay, C-band, X-band

\section{C-Bant ve X-Bant Uygulamaları için İyileștirilmiş Kazanç ve Grup Gecikme Özelliklerine Sahip Çift Bantlı Yama Anteni}

Öz

Bu çalışmada, radar ve uydu iletişiminde C-bandı ve X-bandı uygulamaları için iyileştirilmiş kazanç ve grup gecikme özelliklerine sahip bir çift bantlı yama anten önerilmiştir. Çalışmada, geleneksel kare yama anten, zemin düzlemi kısmen kaldırılarak ve yama köşeleri yuvarlatılarak modifiye edilmiştir. Yuvarlatılmış yama köşelerinin yarıçapı, en iyi anten performansını elde etmek için parametrik çalışma ile belirlenmiştir. Bu parametrik çalışmaya göre yarıçapın değeri $2 \mathrm{~mm}$ olarak ayarlanmıştır. Anten performansı hem zaman hem de frekans alanlarında analiz edilmiştir. Geri Dönüş Kaybı, Duran Dalga Oranı, kazanç, ışıma örüntüsü ve grup gecikmesi CST Microwave Studio programı ile incelenmiştir. Simülasyon sonuçlarını doğrulamak için deneysel çalışma da yapılmıştır. Sonuçlar, köşesi yuvarlatılmış yaması ve kısmi zemin düzlemi olan antenin çift bant özelliğine sahip olduğunu göstermektedir. İki rezonans frekansı, simülasyon sonuçlarında $6,85 \mathrm{GHz}$ ve $9,1 \mathrm{GHz}$, ölçüm sonuçlarında ise $6,56 \mathrm{GHz}$ ve

*Sorumlu yazar (Corresponding author): Şule ÇOLAK, scolak@atu.edu.tr 

Applications

9,12 GHz'dir. Antenin maksimum kazancı 5,8 dB'dir. Ayrıca, ilgili frekans aralığında grup gecikme değişimi çok küçüktür. Böylelikle, önerilen antenin geleneksel kare yama antenine kıyasla artırılmış bant genişliğine, iyileştirilmiş kazanca ve daha tekdüze grup gecikmesine sahip olduğu doğrulanmıştır. Önerilen çift bantlı anten, radar ve uydu iletişiminde C-bandı ve X-bandı uygulamaları için uygun kazanç ve tekdüze grup gecikme özellikleri ile oldukça ümit verici bir yapıdır.

Anahtar Kelimeler: Anten tasarımı, Yama anten, Kazanç, Grup gecikmesi, C bant, X bant

\section{INTRODUCTION}

Microstrip patch antenna is composed of a radiating patch, dielectric substrate and ground plane [1]. Different forms are used for the radiating patch as rectangular, square, elliptic, circular, triangular, trapezoid, L-shaped, circular disc, and star shaped [1-10]. Several feeding techniques for these antennas are coaxial cable, microstrip line, aperture coupled feed and proximity coupled feed [11-14]. Transmission line model, cavity model and methods of moment are some approaches used for analysing these antennas $[15,16]$.

Microstrip patch antennas have low profile, low cost, easily integration and mechanically robustness properties [1-20]. These features make them highly popular for many applications, such as microwave imaging, ground penetrating radar, radio frequency identification and global positioning systems. However, these types of antennas are lack of gain and they suffer from narrow bandwidth. Hence, various modifications are made in the antenna structures by many researchers to overcome these disadvantages [1734]. These modifications include using electromagnetic bandgap structures $[18,19]$, adding slit lines and metallic strips enclosing the radiating patch [20-22], slotting etches on patch or ground plane [23-25], rounding [26-30] or truncating [30$32]$ the corners of the patch and ground plane to improve the antenna behaviour. As a result of modification and improvement methods, numerous microstrip patch antennas are designed and analysed to enhance antenna behaviour by examining Return Loss $\left(S_{11}\right)$, bandwidth, gain, and radiation pattern. Additionally, there are many studies conducted to improve antenna performance in C- and X-bands [33-43].
This paper presents the improvement of square patch antenna by enhancing the gain and group delay parameters in the $\mathrm{C}$ - and $\mathrm{X}$ - bands. For this purpose, the antenna is modified by using partial ground plane and rounded patch corners. Return Loss $\left(\mathrm{S}_{11}\right)$, Voltage Standing Wave Ratio (VSWR), radiation pattern, gain and group delay are investigated over the range covering the $\mathrm{C}$ - and $\mathrm{X}$ bands. The designed antennas are also examined experimentally to verify the simulation results. CST Microwave Studio is used to design and analyse the antennas.

\section{THE SQUARE PATCH ANTENNA}

\subsection{Antenna Design}

Figure 1 illustrates the antenna geometry. The antenna is designed by using FR4 substrate with relative permittivity of 4.3 and loss tangent of 0.025. Physical parameters of the antenna are given in Table 1. Gaussian pulse, which is the default excitation in CST Microwave Studio, is applied as the input signal. The Fourier Transform of this signal has also Gaussian shape in frequency domain. This signal facilitates analysis in time and frequency domains. S-parameters can easily be calculated accurately over the frequency range of interest.

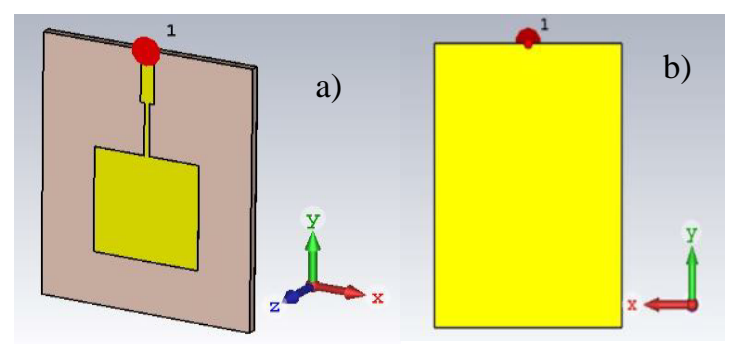

Figure 1. Designed antenna a) Perspective and b) Back views 
Table 1. Physical parameters of the antenna

\begin{tabular}{|l|c|c|}
\hline Patch length & Lp & $20 \mathrm{~mm}$ \\
\hline Patch width & Wp & $20 \mathrm{~mm}$ \\
\hline Matching line width & Wm & $0.99 \mathrm{~mm}$ \\
\hline Matching line length & Lm & $10 \mathrm{~mm}$ \\
\hline Feed line width & Wf & $2.52 \mathrm{~mm}$ \\
\hline Feed line length & Lf & $10 \mathrm{~mm}$ \\
\hline Substrate thickness & h & $1.6 \mathrm{~mm}$ \\
\hline
\end{tabular}

\subsection{Return Loss and VSWR}

Figures $2 \mathrm{a}$ and $2 \mathrm{~b}$ show the $\mathrm{S}_{11}$ and VSWR characteristics of the designed antenna, respectively. $S_{11}$ is below $-10 \mathrm{~dB}$ and VSWR is below 2 at six frequency intervals. Resonance frequencies are $3.48,6.46,7.28,8.00,9.75$ and $10.76 \mathrm{GHz}$, respectively. Return Loss values at these frequencies are $-14.21,-11.75,-16.07$, $-19.31,-12.21$ and -16.95 dB. Similarly, VSWR values at these resonance frequencies are 1.50 , $1.70,1.37,1.26,1.65$ and 1.33 , respectively. As it's seen, this square patch antenna has some notches in the frequency range of interest.

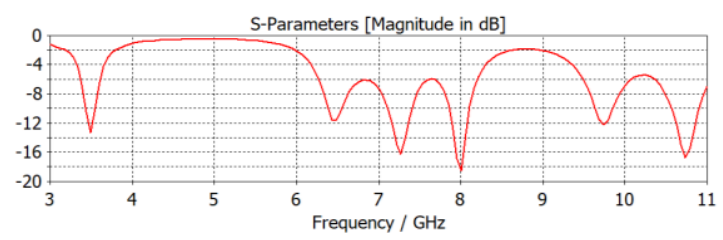

a)

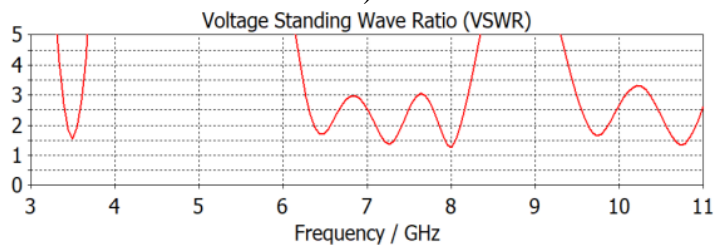

b)

Figure 2. a) Return Loss and b) VSWR of the square patch antenna

\section{IMPROVEMENT OF ANTENNA PERFORMANCE}

\subsection{Ground Plane Effect}

In order to obtain the desired radiation performance, the first step is to modify the antenna by partially removing the ground plane $[18,26,44]$. Figure 3 illustrates the perspective and back views of this antenna.

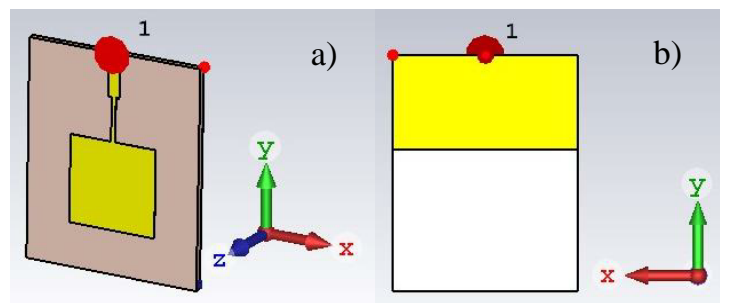

Figure 3. Modified antenna with partial ground plane a) Perspective view b) Back view

As seen from $S_{11}$ and VSWR graphs in Figure 4, the designed antenna shows dual band characteristic. The first band is in the range from 6.38 to $7.61 \mathrm{GHz}$ and the second one is in the range from 8.52 to 9.30 $\mathrm{GHz}$. The two resonance frequencies are $6.69 \mathrm{GHz}$ and $8.96 \mathrm{GHz}$ with Return Loss values of $-15.76 \mathrm{~dB}$ and $-27.65 \mathrm{~dB}$, respectively. VSWR is below 2 throughout the same ranges. VSWR values at two resonance frequencies are 1.39 and 1.09. Corresponding bandwidth for each band is $1.23 \mathrm{GHz}$ and $780 \mathrm{MHz}$, respectively.

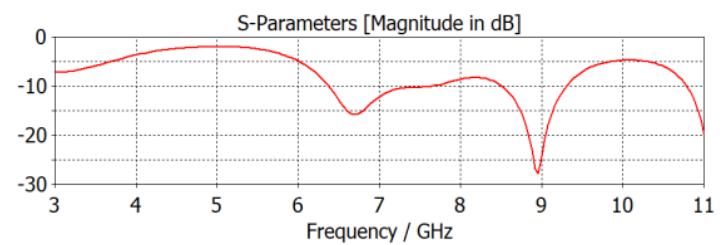

a)

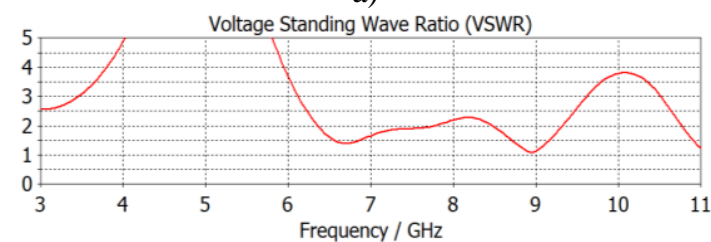

b)

Figure 4. a) Return Loss and b) VSWR for square patch antenna with partial ground

\subsection{Rounded Corner Effect}

The patch corners are rounded to further improve antenna performance in $\mathrm{C}$ and $\mathrm{X}$ bands. Figure 5 shows the perspective and back views of the proposed antenna. 


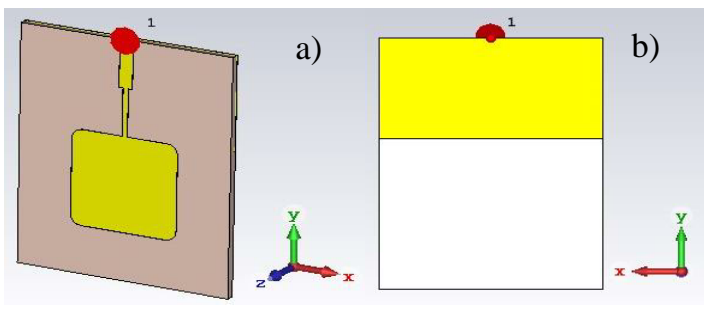

Figure 5. Rounded square patch antenna with partial ground a) perspective and b) back view

A parametric study is carried out to specify the radius of the rounded corners. Radius $\mathrm{r}$ is changed from $2 \mathrm{~mm}$ to $10 \mathrm{~mm}$, iteratively. When $\mathrm{r}$ reaches to $10 \mathrm{~mm}$, the patch shape starts to deteriorate. According to this parametric study, $\mathrm{r}=2 \mathrm{~mm}$ gives the best Return Loss characteristics. Hence, the radius of the rounded corners is set to $2 \mathrm{~mm}$ in the design.

$\mathrm{S}_{11}$ and VSWR graphs are shown in Figures 6a and $6 \mathrm{~b}$, respectively. Again, the antenna has dual band characteristic. The first band is from $6.48 \mathrm{GHz}$ to $7.84 \mathrm{GHz}$ and the second is from $8.68 \mathrm{GHz}$ to $9.47 \mathrm{GHz}$. The two resonance frequencies are 6.85 $\mathrm{GHz}$ and 9.1 GHz. Return Loss values for these resonance frequencies are $-15.24 \mathrm{~dB}$ and $-22.22 \mathrm{~dB}$, respectively. Correspondingly, VSWR values at the resonance frequencies are 1.42 and 1.17. The first bandwidth is $1.36 \mathrm{GHz}$ and the second bandwidth is $790 \mathrm{MHz}$. As seen, this antenna has broader bandwidth for each band as compared to the previous structure.

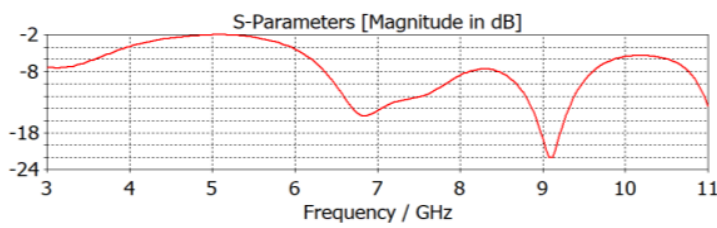

a)

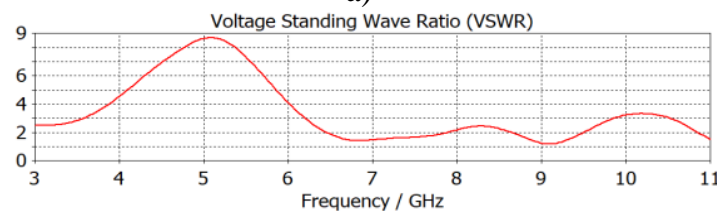

b)

Figure 6. a) Return Loss and b) VSWR for rounded square patch antenna with partial ground plane
Figures $7 \mathrm{a}$ and $7 \mathrm{~b}$ illustrate the $\mathrm{S}_{11}$ and VSWR comparison of three antenna types. The figures clearly show the improvement achieved by using partial ground plane and rounded patch corners.

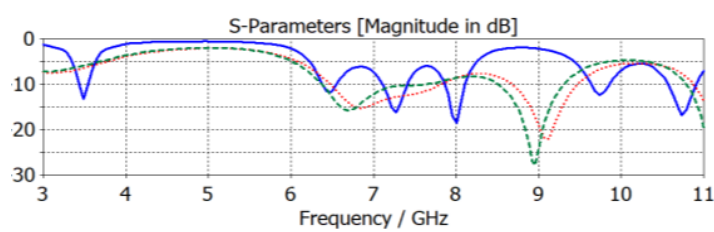

a)

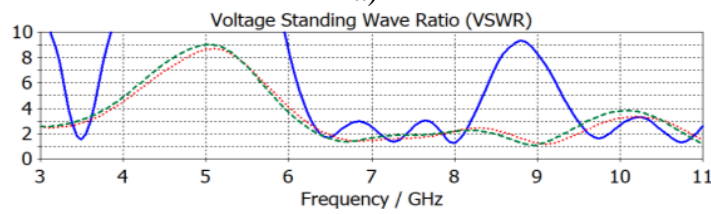

b)

- Ordinary Square Patch Antenna
..... Rounded Patch Antenna with ...

..- Square Patch Antenna with P...

Figure 7. a) Return Loss and b) VSWR comparison of - ordinary square patch, ----- square patch with partial ground, ..... rounded patch with partial ground

\subsection{Antenna Gain}

Maximum gains for the three antenna types are depicted in Figure 8. Among the three antenna types, the antenna with rounded patch corners and partial ground plane yields the highest gain in the related frequency range. The gains for this antenna are 4.1 and $5.8 \mathrm{~dB}$ at the resonance frequencies of $6.85 \mathrm{GHz}$ and $9.1 \mathrm{GHz}$, respectively.

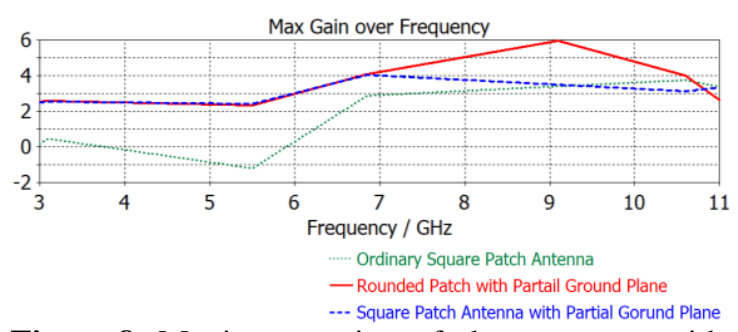

Figure 8. Maximum gains of the antennas with _ rounded square patch with partial ground plane, ------- square patch with partial ground plane, ...... ordinary square patch antenna 
Apparently, rounded square patch antenna with partial ground plane has the best performance among the presented antennas. While partial ground plane provides enhanced bandwidth and gain, rounded patch corners further improve the gain.

\subsection{Radiation Pattern}

In the previous section, the antenna with rounded patch corners and partial ground plane is seen to be more suitable for dual band operation in $\mathrm{C}$ - and $\mathrm{X}$ bands. Thus, in this section, radiation pattern is examined for this structure.

Radiation patterns for the proposed antenna are illustrated in Figures 9 and 10 at two resonance frequencies. As seen from these two figures, radiation pattern is directional at $\phi=90^{\circ}$ and $\theta=90^{\circ}$ planes. Main lobe magnitudes at $6.85 \mathrm{GHz}$ are $5.47 \mathrm{~V}$ and $8.44 \mathrm{~V}$ for $\phi=90^{\circ}$ and $\theta=90^{\circ}$ planes, respectively. Likewise, main lobe magnitudes at $9.1 \mathrm{GHz}$ are $4.63 \mathrm{~V}$ and $10.70 \mathrm{~V}$ for $\phi=90^{\circ}$ and $\theta=90^{\circ}$ planes, respectively.

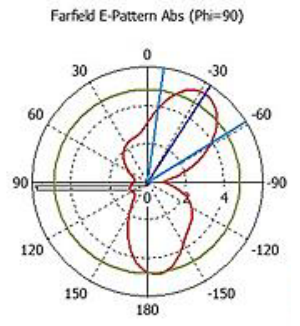

Theta / Degree vs. V

a)

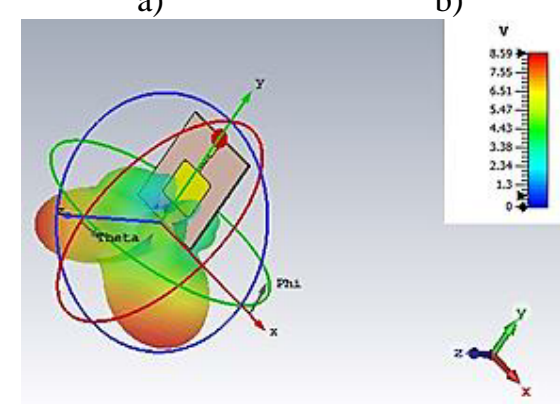

c)

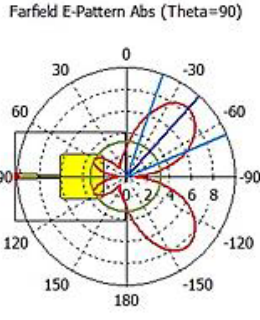

Phi / Degree vs. $V$

b)

olar pattern and c) $3 \mathrm{D}$ radiation pattern of the proposed antenna at $6.85 \mathrm{GHz}$

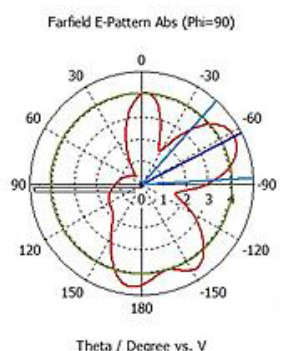

a)

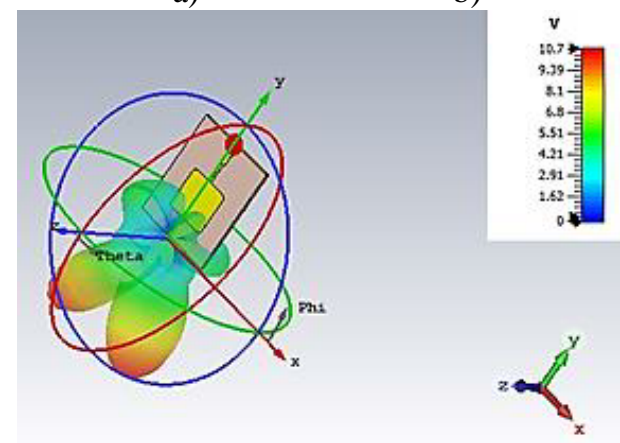

c)

Figure 10. a) $\phi=90^{\circ}$, b) $\theta=90^{\circ}$ polar pattern and c) $3 \mathrm{D}$ radiation pattern of the proposed antenna at $9.1 \mathrm{GHz}$

\section{TIME DOMAIN ANALYSIS}

\subsection{Group Delay}

Group delay is significant for analysing time domain characteristics of an antenna. It does not only give idea about the phase but also signal distortion level of the structure $[45,46]$. For a nondistortion system, group delay should not vary significantly over the related frequency range. In fact, if the group delay fluctuates more than $1 \mathrm{~ns}$, the condition for linear phase response is not satisfied, and degradations occur in the signal [46]. Henceforth, group delay is a crucial parameter in time domain analysis. In this section, transmission coefficient magnitude $\left|S_{21}\right|$ and group delay are examined for all configurations.

Thus, for group delay analysis, two identical antennas are placed in the far field region of each other as shown in Figure 11. Then, $\left|S_{21}\right|$ and group 
delay parameters are simulated and their variations are illustrated in Figures 12-14.

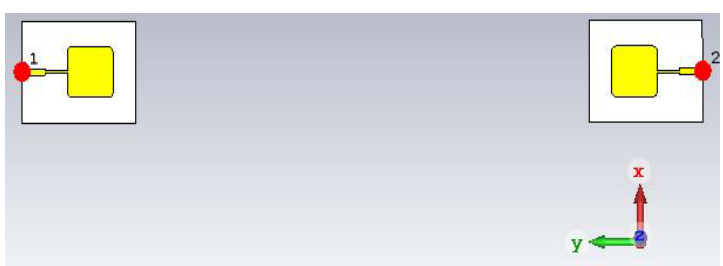

Figure 11. Two identical antennas placed in the far field region of each other for group delay analysis

Figure 12 indicates transmission coefficient magnitude and group delay graphs for the squareshaped patch antenna with full ground. In the figure, $\left|S_{21}\right|$ has noticeable variations and group delay has many ripples in the related frequency range, thus deformations occur in the signal shape.

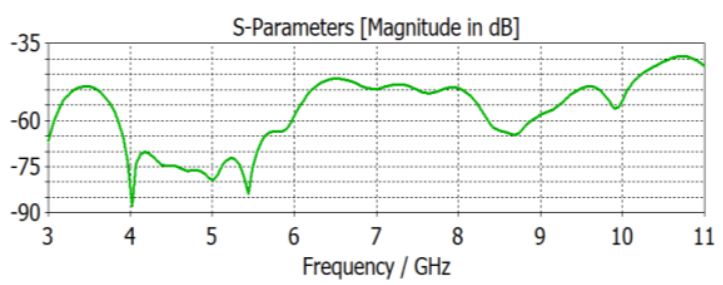

a)

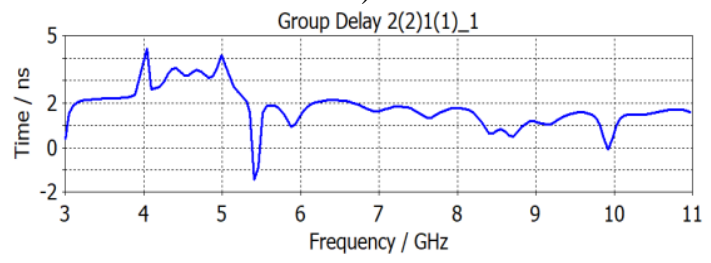

b)

Figure 12. a) Transmission Coefficient and b) Group Delay of the square patch antenna with full ground plane

Next, the second structure, the antenna with square patch and partial ground plane, is analysed in terms of transmission coefficient and group delay characteristics in the $\mathrm{C}$ and $\mathrm{X}$ bands. As depicted in Figure 13, transmission coefficient and group delay for this antenna are more uniform and the variations are very small as compared to the previous structure.

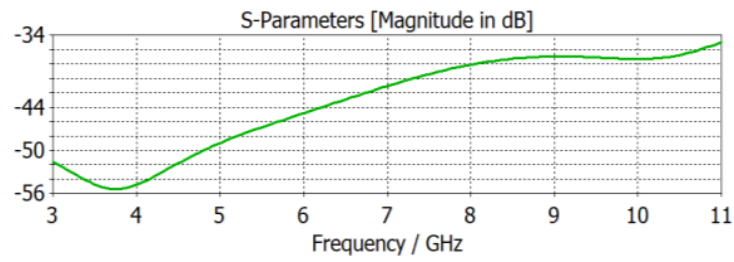

a)

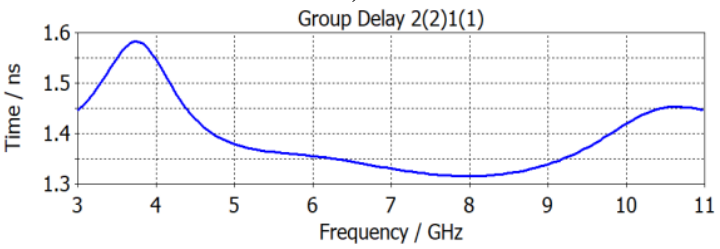

b)

Figure 13. a) Transmission Coefficient and b) Group delay of the antenna with square patch and partial ground plane

The transmission coefficient and group delay of the rounded square patch antenna with partial ground plane are examined in Figure 14. It is obvious from the figure that the transmission coefficient and group delay are uniform and their variations are very small in the range. In pass band systems, less variation in the group delay indicates better linear phase response and less distortion in signal shape. Therefore, this antenna shows a good performance with its small variation in the group delay and less distortion in the waveform.

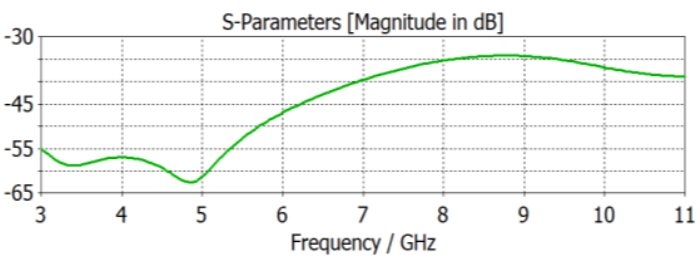

a)

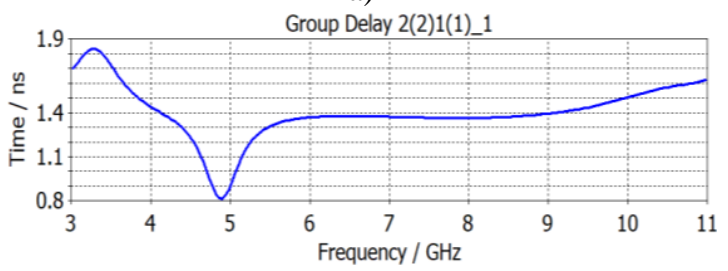

b)

Figure 14. a) Transmission Coefficient and b) Group Delay of the rounded square patch antenna with partial ground 


\section{MEASUREMENT RESULTS}

Antennas are fabricated with FR-4 substrate material $\left(\varepsilon_{\mathrm{r}}=4.3, \mathrm{~h}=1.6 \mathrm{~mm}, \tan \delta=0.025\right)$ by using PCB prototyping machine. The square patch antenna is shown in Figure 15 and the rounded patch antenna with partial ground plane is shown in Figure 16. The length of partial ground plane is $20 \mathrm{~mm}$. SMA connector $(50 \Omega)$ is used to feed the fabricated antennas. The reflection coefficient and VSWR characteristics of two fabricated antennas are measured via PNA-L Network Analyzer.

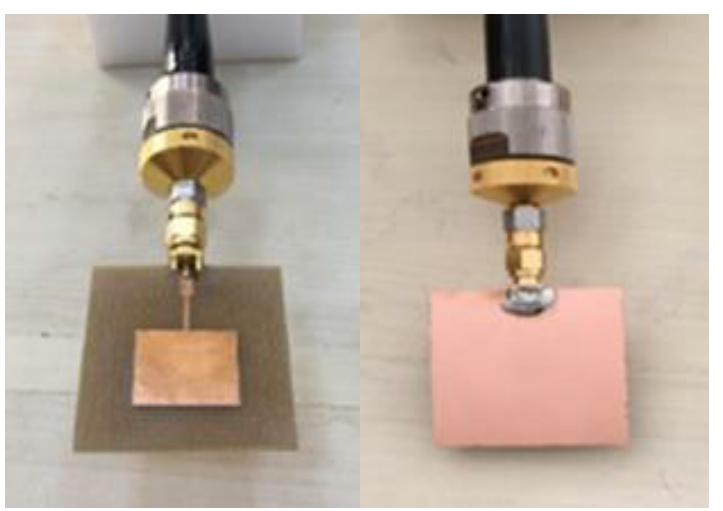

a) b)

Figure 15. a) Front and b) back views of the fabricated square patch antenna with full ground plane

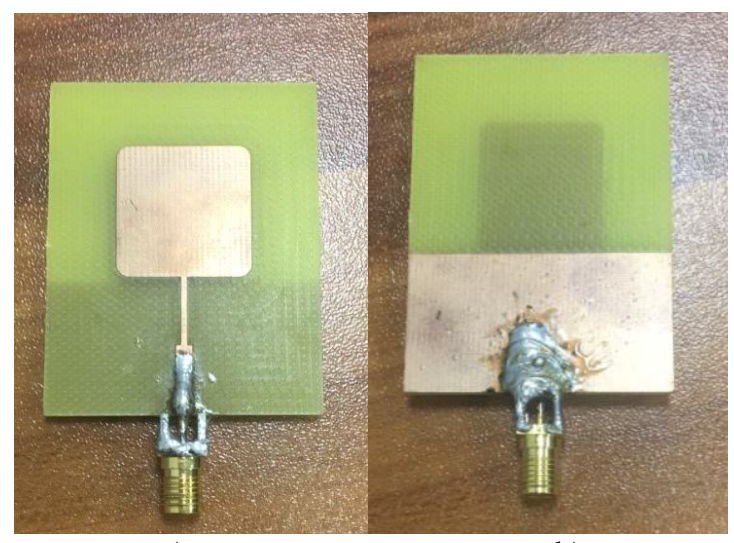

a)

Figure 16. a) Front and b) back views of the fabricated rounded patch antenna with partial ground plane

The measured and simulated results for $S_{11}$ and VSWR of the square patch antenna with full ground plane are illustrated in Figures 17 and 18, respectively. It is outlined from these figures that measurement results show good agreement with the simulation results. As expected, the square patch antenna with full ground plane results in multiple notches in the related frequency band. Table 2 depicts measurement results for the fabricated square patch antenna with full ground plane.

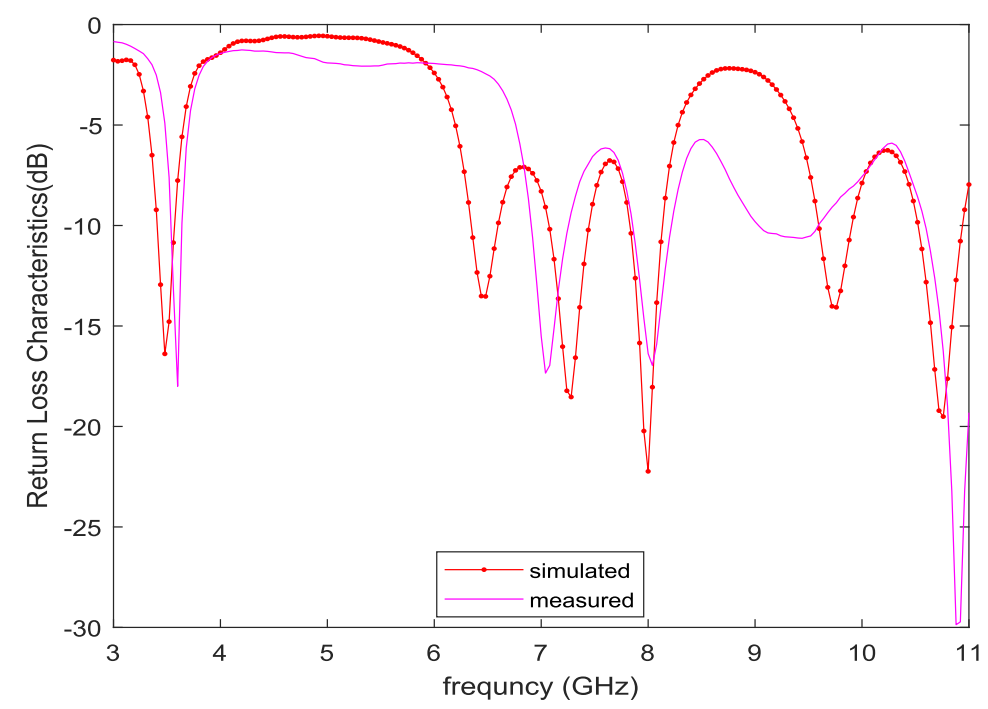

Figure 17. Return Loss characteristics of square patch antenna with full ground plane 
A Dual-Band Patch Antenna with Improved Gain and Group Delay Characteristics for C-Band and X-Band Applications

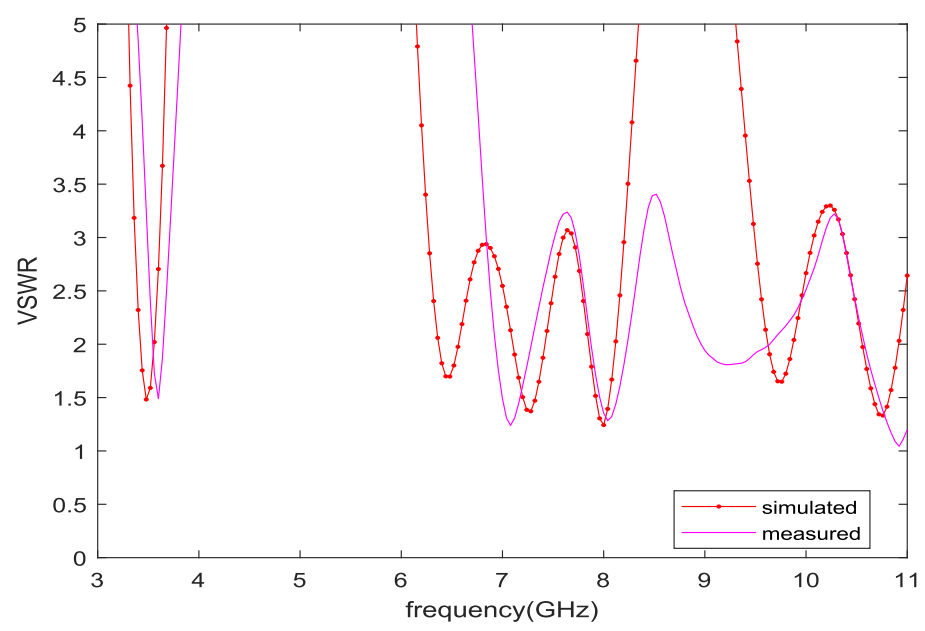

Figure 18. VSWR characteristics of square patch antenna with full ground plane

Table 2. Measurement results of the square patch antenna with full ground plane

\begin{tabular}{|c|c|c|c|}
\hline $\begin{array}{c}\text { Resonance } \\
\text { frequency }\end{array}$ & $\begin{array}{c}\text { Return } \\
\text { loss }\end{array}$ & VSWR & $\begin{array}{c}\text { Corresponding } \\
\text { bandwidth }\end{array}$ \\
\hline $3.60 \mathrm{GHz}$ & $-14.79 \mathrm{~dB}$ & 1.49 & $\begin{array}{c}80 \mathrm{MHz} \\
(3.64-3.56 \mathrm{GHz})\end{array}$ \\
\hline $7.08 \mathrm{GHz}$ & $-19.80 \mathrm{~dB}$ & 1.24 & $\begin{array}{c}280 \mathrm{MHz} \\
(6.96-7.24 \mathrm{GHz})\end{array}$ \\
\hline $8.04 \mathrm{GHz}$ & $-18.60 \mathrm{~dB}$ & 1.24 & $\begin{array}{c}360 \mathrm{MHz} \\
(7.88-8.24 \mathrm{GHz})\end{array}$ \\
\hline $9.24 \mathrm{GHz}$ & $-11.05 \mathrm{~dB}$ & 1.80 & $\begin{array}{c}600 \mathrm{MHz} \\
(9-9.6 \mathrm{GHz})\end{array}$ \\
\hline
\end{tabular}

The measured and simulated $\mathrm{S}_{11}$ and VSWR plots of the rounded square patch antenna with partial ground are illustrated in Figures 19 and 20. In these figures, there are some discrepancies between simulation and measurement results. These discrepancies arise from the SMA connector, which may lead to conductor loss when integrated into antenna. Furthermore, the resonance frequency shifts between measured and simulated results are due to soldering process and impedance mismatch at the antenna input. The measurement results for the fabricated antenna are given in Table 3 .

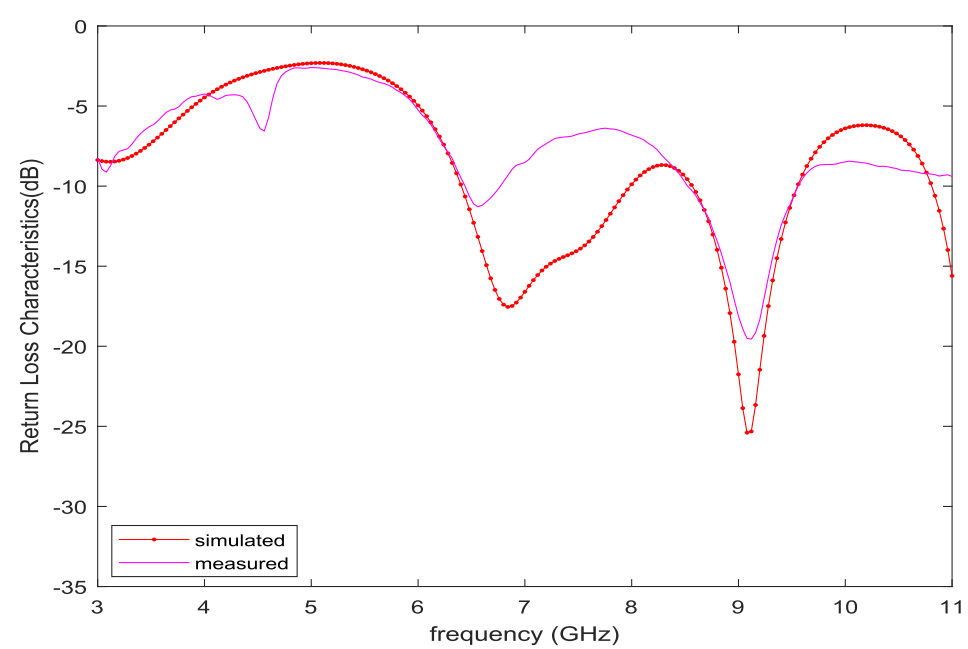

Figure 19. Return Loss characteristics of rounded patch antenna with partial ground plane 


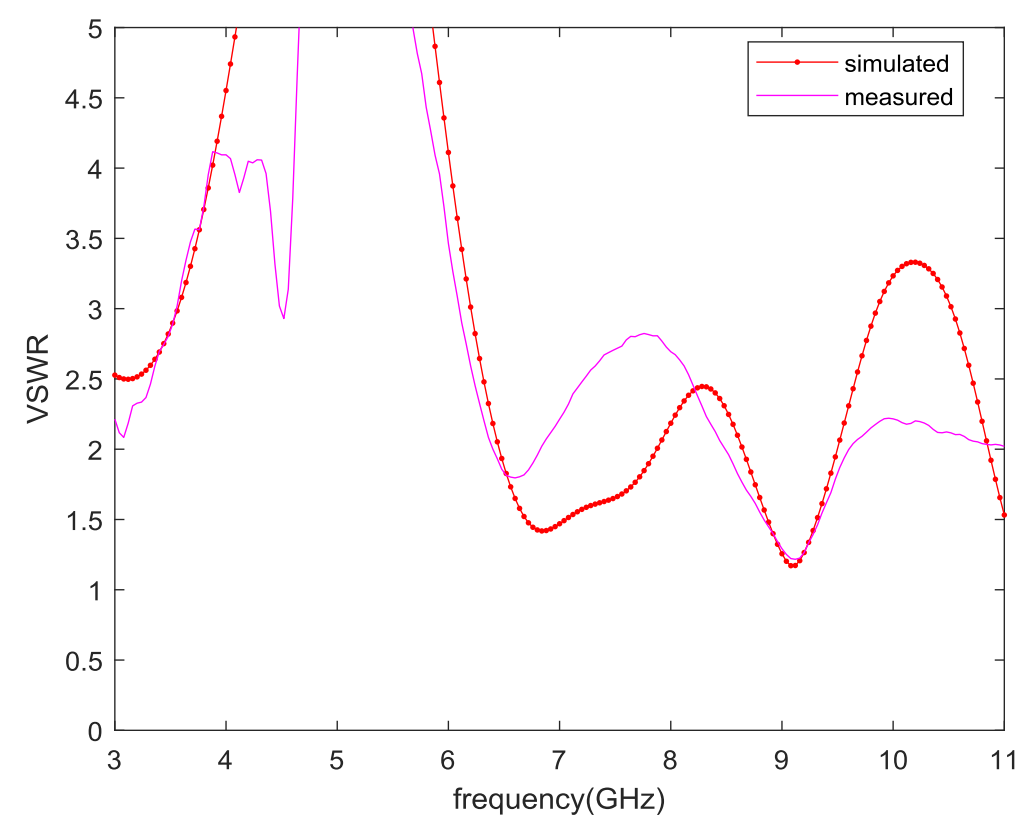

Figure 20. VSWR characteristics of rounded patch antenna with partial ground plane

Table 3. Measurement results of rounded patch antenna with partial ground plane

\begin{tabular}{|c|c|c|c|}
\hline $\begin{array}{c}\text { Resonance } \\
\text { frequency }\end{array}$ & $\begin{array}{c}\text { Return } \\
\text { loss }\end{array}$ & VSWR & $\begin{array}{c}\text { Corresponding } \\
\text { bandwidth }\end{array}$ \\
\hline $6.56 \mathrm{GHz}$ & $\begin{array}{c}-11.29 \\
\mathrm{~dB}\end{array}$ & 1.80 & $\begin{array}{c}28 \mathrm{MHz} \\
(6.48-6.76 \mathrm{GHz})\end{array}$ \\
\hline $9.12 \mathrm{GHz}$ & $\begin{array}{c}-19.55 \\
\mathrm{~dB}\end{array}$ & 1.22 & $\begin{array}{c}920 \mathrm{MHz} \\
(8.6-9.52 \mathrm{GHz})\end{array}$ \\
\hline
\end{tabular}

Table 4 depicts the comparison of the proposed antenna in this research with similar studies in the literature in terms of Bandwidth, Gain, and Group Delay characteristics. It is seen that the proposed antenna has higher gain than most of the studies in the table. This work also analysis the time domain characteristics by examining group delay parameter. Thus, it is verified that the designed antenna in this paper transmits the signal with less distortion for $\mathrm{C}$ and $\mathrm{X}$ bands applications.

Table 4. Comparison of proposed antenna with similar studies

\begin{tabular}{|c|c|c|c|c|}
\hline Ref. & Dim. $\left(\mathrm{mm}^{3}\right) /$ Material & Operating freq./Bandwidth & Gain & Group delay \\
\hline$[25]$ & $25 \times 24.5 \times 0.76$ Rogers & $\begin{array}{c}2.4-2.484 \mathrm{GHz}(84 \mathrm{MHz}) \\
\begin{array}{c}3.3-3.69 \mathrm{GHz}(39 \mathrm{MHz}) \\
5.15-5.35 \mathrm{GHz}(200 \mathrm{MHz})\end{array}\end{array}$ & \multirow{2}{*}{$4.8 \mathrm{~dB}$} & NA \\
\hline$[26]$ & $30 \times 35 \times 1.6 \mathrm{FR}-4$ & $3.42-11.7 \mathrm{GHz}(8.28 \mathrm{GHz})$ & $6 \mathrm{dBi}$ & NA \\
\hline$[27]$ & $10 \times 7.5 \times 0.508 \mathrm{Rogers}$ & $9.85-10.15 \mathrm{GHz}(300 \mathrm{MHz})$ & $5.2 \mathrm{~dB}$ & NA \\
\hline$[28]$ & $30 \times 39 \times 1.6 \mathrm{FR}-4$ & $3.28-12.44 \mathrm{GHz}(9.16 \mathrm{GHz})$ & $3.02 \mathrm{dBi}$ & NA \\
\hline$[29]$ & $12.7 \times 15.2 \times 1.6 \mathrm{FR}-4$ & $3.21-12.72 \mathrm{GHz}(9.51 \mathrm{GHz})$ & $2.87 \mathrm{dBi}$ & NA \\
\hline$[32]$ & $26 \times 30 \times 1.6 \mathrm{FR}-4$ & $3.1-14 \mathrm{GHz}(10.9 \mathrm{GHz})$ & $3.8 \mathrm{~dB}$ & NA \\
\hline$[35]$ & $32 \times 33.5 \times 1.5 \mathrm{NA}$ & $\begin{array}{c}6.71-7.18 \mathrm{GHz}(470 \mathrm{MHz}) \\
8.45-8.9 \mathrm{GHz}(500 \mathrm{MHz})\end{array}$ & $2.91 \mathrm{~dB}$ & NA \\
\hline This work & $40 \times 50 \times 1.6 \mathrm{FR}-4$ & $\begin{array}{l}6.48-7.84 \mathrm{GHz}(1.36 \mathrm{GHz}) \\
8.68-9.47 \mathrm{GHz}(790 \mathrm{MHz})\end{array}$ & $5.8 \mathrm{~dB}$ & YES \\
\hline
\end{tabular}


A Dual-Band Patch Antenna with Improved Gain and Group Delay Characteristics for C-Band and X-Band Applications

\section{CONCLUSION}

In this study, a dual band patch antenna is proposed with improved gain and group delay characteristics in $\mathrm{C}$ and $\mathrm{X}$ bands for radar and satellite communications. The ordinary square patch antenna is narrowband by its nature and it does not perform well within the frequency range of interest. Thus, to improve the antenna performance, the patch antenna structure is modified by partially removing the ground plane and rounding the patch corners.

The proposed antenna is analysed both in frequency and time domain by examining Return Loss, gain, radiation pattern, and group delay characteristics. According to obtained results, rounded square patch antenna with partial ground plane performs well in the related frequency range. The structure has enhanced bandwidth, improved gain, and uniform group delay in C-band and Xband. For verification purposes, the designed antennas are also analysed experimentally. The measurement results are in good agreement with the simulation results. Consequently, the proposed dual-band patch antenna is a quite promising structure for C-band and X-band applications in radar and satellite communications.

\section{ACKNOWLEDGEMENT}

This work was supported by the Scientific Research Projects Unit (BAP) in Adana Alparslan Türkeş Science and Technology University. Project No: Mühdbf. Eem. 2015-18, Project Title: Investigation and Improvement of Ultra-Wideband Antenna Characteristics.

\section{REFERENCES}

1. Saidulu, V., Rao, K.S., Rao, P.S., 2013. The Characteristics of Rectangular and Square Patch Antennas with Superstrates, International Journal of Engineering Sciences and Emerging Technologies, 6(3), 298-307.

2. Gençoğlan, D.N., Arslan, M.T., Çolak, Ş., Yildirim, E., 2020. Ultra-Wideband (UWB) Characteristic Estimation of Elliptic Patch
Antenna Based on Machine Learning Techniques, Frequenz, 74(9-10), 351-358.

3. Cai, Y., Qian, Z.P., Cao, W.Q., Zhang, Y.S., Guan, D.F., 2014. Dual Polarized Notch-etched Circular Patch Antenna Loaded with Metamaterial Structure, Frequenz, 68(5-6), 211-216.

4. Shaw, M., Mandal, N., Gangopadhyay, M., 2020. A Low Profile Miniaturized Circular Microstrip Patch Antenna for Dual-band Application, Frequenz, 74(9-10), 333-349.

5. Gouda, M., Yousef, M.Y, 2012. Bandwidth Enhancement Techniques Comparison for Ultra-wideband Microstrip Antennas for Wireless Application, Journal of Theoretical and Applied Information Technology, 35(2), 184-193.

6. Cao, X., Wang, D.F., Gu, Z., Liu, Y., Liu, Y., Tian, X.J., 2018. A Printable Trapezoidstructured UWB Micro-strip Antenna Applicable to MEMS Wireless Sensor Networks, Microsystem Technologies, 24(6), 2499-2506.

7. Yang, X., Liu, X., Song, C., 2015. A Tripleband Monopole Planar Antenna for WLAN and WiMAX Applications, Frequenz, 69(7-8), 305-309.

8. Rao, G.S., Kumar, S.S., Pillalamarri, R., 2015. Analysis and Review on Usage of Broadband Techniques in Design of Printed Antennas for UWB Communications, Microsystem Technologies, 21(7), 1423-1426.

9. Rao, G.S., Kumar, S.S., Pillalamarri, R., 2015. Small Modified Printed Planar Ultrawide Band Disc Antennas with Etched Ground Plane, Microsystem Technologies, 21(5), 1081-1086.

10. Nasr, M.A., Ouda, M.K., Ouda, S.O., 2013. Design of Star-shaped Microstrip Patch Antenna for Ultra-wideband (UWB) Applications, International Journal of Wireless \& Mobile Networks, 5(4), 65-73.

11. Gupta, M., Mathur, V., Kumar, A., Saxena, V., Bhatnagar, D., 2019. Microstrip Hexagonal Fractal Antenna for Military Applications, Frequenz, 73(9-10), 321-330.

12. Malaisamy, K., Santhi, M., Robinson, S., Wasim, M., Murugapandiyan, P., 2020. Design and Development of Cross Dipole Antenna for 
Satellite Applications, Frequenz, 74(7-8), 229-237.

13. Raghavendra, C., Suma, M., Krishna, A.A., 2016. Design and Analysis of Circular Patch Antenna for UWB Applications, Indian Journal of Science and Technology, 9(1-5).

14. Balanis, C.A., 2005. Antenna Theory: Analysis and Design, New Jersey John Wiley and Sons.

15. Bernard, V., Iloh, J.P.I, 2013. Microstrip Antenna Design Using Transmission Line Model, International Journal of Emerging Technology and Advanced Engineering, 3(11), 410-415.

16. Banerjee, P., Bezboruah, T., 2015. Comparative Study of Transmission Line and Cavity Model of Rectangular Microstrip Antenna, International Journal of Natural Sciences Research, 3(6), 76-82.

17. Punitharaj, D., Kalaimani, S., 2013. Design and Fabrication of Microstrip Antenna for UWB Applications, International Journal of Emerging Trends in Electrical and Electronics, 3(2), 60-63.

18. Karamzadeh, S., Rafiei, V., 2020. Dual-band Antenna Modification by Using Dual Bad EBG Structure for WLAN/WiMAX Applications, Journal of Instrumentation, 15, (4).

19. Mouhouche, F., Azrar, A., Dehmas, M., Djafri, K., 2018. Design a Compact UWB Monopole Antenna with Triple Band-notched Characteristics Using EBG Structures, Frequenz, 72(11-12), 479-487.

20. Jaglan, N., Kanaujia, B.K., Gupta, S.D., Srivastava, S., 2017. Dual Band Notched EBG Structure Based UWB MIMO/diversity Antenna with Reduced Wide Band Electromagnetic Coupling, Frequenz, 71,(1112), 555-565.

21. Verma, M.K., Kanaujia, B.K., Saini, J.P., Saini P.S., 2020. A Broadband Circularly Polarized Cross-slotted Patch Antenna with Horizontal Meandered Strip (HMS), Frequenz, 74(5-6), 191-199.

22. Pan, C.Y., Su, C.C., Yang, W.L., 2018. CPWfed Circularly Polarized Slot Antenna with Small Gap and Stick-shaped Shorted Strip for UHF FRID Readers, Frequenz, 72(5-6), 181-188.
23. Mishra, B., Singh, V., Singh, R., 2017. Dual and Wide-band Slot Loaded Stacked Microstrip Patch Antenna for WLAN/WiMAX Applications, Microsystem Technologies, 23(8), 3467-3475.

24. Patil, S., Singh, A.K., Kanaujia, B.K., Yadava R.L., 2018. Design of Dual Band Dual Sense Circularly Polarized Wide Slot Antenna with C-shaped Radiator for Wireless Applications, Frequenz, 72(7-8), 343-351.

25. Wang, Z., Peng, Y., Ran, Y., Qin, W., Yang, H., 2016. Small Printed Tri-band Antenna with Reduced Ground-plane Effect, Frequenz, 70 (5-6), 219-224.

26. Awad, N.M., Abdelazeez, M.K., 2015. UWB Antenna with Round Steps, IEEE International Symposium on Antennas and Propagation \& USNC/URSI National Radio Science Meeting, 1954-1955.

27. Farahbakhsh,A., D., Zarifi, 2020. Miniaturization of Patch Antennas by Curved Edges, AEU-international Journal of Electronics and Communications, 117.

28. Ahire, D.D., Kharate, G.K., 2017. Corner Rounded UWB Monopole Rectangular Microstrip Patch Antenna, IEEE Applied Electromagnetics Conference (AEMC), 1-2.

29. Ahire, D.D., Kharate, G.K., 2018. Defective Ground Corner Rounded Ultra-wideband Microstrip Patch Antenna for Bio-medical Applications, ICTAC Journal on Microelectronics, 3(4), 462-466.

30. Mandal, K. 2016. A Review on Printed Monopole Antenna for UWB Applications, International Journal of Advanced Research in Computer and Communication Engineering, 4(2), 508-510.

31. Krishna, T.R., Madhav, B.T.P., Geetanjali, S., Parnika, B., Bhargavi, M.L., Tanmai, A.S., Anilkumar, T., 2016. Design and Study of a CPW Fed Truncated Circular Patch Switchable Band-notched UWB Antenna, Int. J. Recent Technol. Eng. IJRTE, 8(1), 3037-3043.

32. Elajoumi, S., Tajmouati, A., Errkik, A., Sanchez, A., Latrach, M., 2017. Microstrip Rectangular Monopole Antennas with Defected Ground for UWB Applications, International Journal of Electrical and Computer Engineering, 7(4), 2027-2035. 
33. Majeed, M.W., Khan, A., Rehman, A.U., Rashid, K., 2011. Microstrip Patch Antennas for Microwave S-band, C-band and X-band Applications, Bahria University Journal of Information \& Communication Technology, 4(1), 36 .

34. Majeed, A.H., Sayidmarie, K.H., 2018. Extended Bandwidth Microstrip Circular Patch Antenna for Dual Band Applications, International Journal of Electrical and Computer Engineering, 8(2), 1056.

35. Joshi, A., Singhal, R., 2019. Coaxially Fed Hexagonal Patch Antenna for C- and X-band Applications with Reduced-ground Plane, ECTI Transactions on Electrical Engineering, Electronics, and Communications, 17(2), 136-143.

36. Bhavani, K.V.L., Khan, H., Madhav, B.T.P., 2015. Multiband Slotted Aperture Antenna with Defected Ground Structure for C and Xband Communication Applications, Journal of Theoretical and Applied Information Technology, 82(3), 454.

37. Prema, N., 2016. Design of Multiband Microstrip Patch Antenna for C and X-band, Optik, 127(20), 8812-8818.

38. Sharma, S., Kumar, G., 2016. A Dual Wideband Stair Shape Microstrip Patch Antenna for C \& X Band, International Journal of Electronics and Communication Engineering (IJECE), 5(4), 1-8.

39. Djengomemgoto, G., Altunok, R., Karabacak, C., İmeci, Ş.T., Durak, T., 2017. Dual-band gemini-shaped Microstrip Patch Antenna for C- Band and X- Band Applications, International Applied Computational Electromagnetics Society Symposium (ACES), 1-2.

40. Kiruthika, R., Shanmuganantham, T., 2017. A Canadian Leaf Shaped Triple Band Patch Antenna with DGS for $\mathrm{X}$ and C-band Applications, International Journal of Electronics and Communication Engineering, 11(4), 502-508.

41. Meloui, M., Essaaidi, M., 2014. A Dual Ultrawide Band Slotted Antenna for C and X-bands Application, Progress in Electromagnetics Research, 47, 91-96.
42. Saini, H., Kaur, A., Thakur, A., Kumar, R., Kumar, N.N, 2016. A Parametric Analysis of Ground Slotted Patch Antenna for X-band Applications, $3^{\text {rd }}$ International Conference on Signal Processing and Integrated Networks (SPIN), 549-552.

43. Salamin, M.A., Ali, W.A.E., Das, S., Zugari, A., 2020. A Novel Etched-substrate Mechanism for Characteristics Improvement of X-band Broadband Printed Monopole Antenna, Microsystem Technologies, 26, 3773-3782.

44. Viswanadha, K., Raghava, N.S., 2020. Design and Analysis of a Multi-band Flower Shaped Patch Antenna for WLAN/WiMAX/ISM Band Applications, Wireless Personal Communications, 1-25.

45. Kasi, B., Ping, L.C., Chakrabarty, K.C., 2011. A Compact Microstrip Antenna for Ultrawideband Applications, European Journal of Scientific Research, 67(1), 45-51.

46. Mazhar, W.M., Tarar, M.A., Tahir, F.A., Ullah, S., Bhatti, F.A., 2013. Compact Microstrip Patch Antenna for Ultra-wideband Applications. PIERS Proceedings, Stockholm, Sweden, 12-15. 